Available online on 15.04.2020 at http://jddtonline.info
Open Access to Pharmaceutical and Medical Research
unrestricted non-commercial use, provided the original work is properly cited

Open $\odot$ Access

Research Article

\title{
Relation between Concentrations of Lead, Cadmium and Mercury in Cord Blood and Prematurity in the Sidi Bel Abbes Region (West of Algeria)
}

\author{
Bouhadiba Hadjer, Demmouche Abbassia* \\ Biotoxicology Laboratory, Department of Biology. Faculty of Naturel Science and life. Djillali Liabes University; Sidi Bel Abbes. Algeria
}

\begin{abstract}
Background: Exposure to heavy metals such as lead, cadmium and mercury during pregnancy carries a great risk to the mother as well as the fetus. Methods: Lead, cadmium and mercury were measured in umbilical cord blood samples of 3 groups women (30 women's for lead, 30 cadmium and 10 from mercury) in maternity of Sidi Bel Abbes region in Algeria between 2016 and 2017.The objective of this study was to measure in the blood of the umbilical cord the concentration of lead $(\mathrm{Pb})$, mercury $(\mathrm{Hg})$ and cadmium $(\mathrm{Cd})$, and to evaluate the relationship between these levels and prematurity. The lead, cadmium and mercury levels were measured by atomic absorption. Results: The study showed obvious variations in, maternal characteristics. The results revealed several factors predisposing to prematurity. The mean concentrations of cord blood lead, cadmium and mercury were; $18.97 \mu \mathrm{g} / \mathrm{L}, 0.26 \mu \mathrm{g} / \mathrm{L}$, and6.20 nmol/L, respectively. There was a highly significant direct correlation between cord lead concentrations and gestational age $(\mathrm{r}=0.43 ; \mathrm{P}=0.017)$, and we found that gestational age and birth weight inversely correlated with cord mercury concentration $(\mathrm{r}=0.44$ and $\mathrm{r}=0.57$ respectively). No correlation was observed between cord cadmium concentrations and gestational age. Conclusion: This study has shown that pregnant women in this region were exposed to high levels for heavy metalswhich need an intervention.
\end{abstract}

Keywords: Lead. Cadmium, Mercury, Pregnancy, Prematurity, Fetal exposure, Algeria.

Article Info: Received 03 Feb 2020; Review Completed 21 March 2020; Accepted 31 March 2020; Available online 15 April 2020

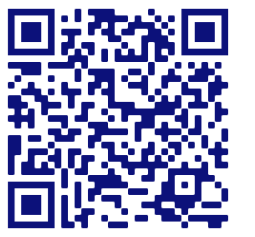

Cite this article as:

Bouhadiba HHadjer, Demmouche A, Relation between Concentrations of Lead, Cadmium and Mercury in Cord Blood and Prematurity in the Sidi Bel Abbes Region (West of Algeria), Journal of Drug Delivery and Therapeutics. 2020; 10(2-s):58-63 http://dx.doi.org/10.22270/jddt.v10i2-s.4020

Pr Abbassia DEMmOUCHE. Professor in Biology,Biotoxicology laboratory, Department of Biology. Faculty of Naturel Science and life. Djillali Liabes University; Sidi Bel Abbes. Algeria

\section{INTRODUCTION:}

Pregnant women and their fetuses are susceptible to the effects of exposure to environmental toxicants including lead, mercury and cadmium. Metals are ubiquitous in the environment, and exposure occurs through ingestion of food, water, soil, or dust; inhalation from air; and through direct contact with consumer products 1 . Exposure to heavy metals during pregnancy carries a great risk to the developing fetus $^{2}$. Metals are potential risk factors for small for gestational age (SGA) births, and are hypothesized to induce growth restriction through oxidative stress mediated pathways $^{3}$. Cigarette smoking is source of cadmium exposure ${ }^{9}$. Scientists suggest that cadmium may damage the placenta and reduce weight of newborn baby in pregnancy 4,5 . Toxicity from mercury may cause learning disabilities and it effects reproductive system and produces defects such as infertility, miscarriage and prematurity 6,7 . The aim of or study was to measure in umbilical cord blood, at delivery, the concentration of lead $(\mathrm{Pb})$, mercury $(\mathrm{Hg})$ and cadmium $(\mathrm{Cd})$, and evaluate the relationship between this levels and prematurity.

\section{PATIENTS AND METHODS:}

A prospective study was conducted in public maternity in Sidi Bel Abbes region (west of Algeria), over a period of 01 years from December 2016 to October 2017. The ethical committee of our department approved the study. After signing a written informed consent, the patients were recruited to the study.

Gestational age patients over 36 weeks of amenorrhea were excluded from the study. Eventually, a total of number 70 pairs of mother-newborn were included in the study. All the patients completed questionnaires including information about age, ethnic origin, Socio-economic level, Level of education, BMI, history for prematurity and abortion and smoking habits.

Five mls of umbilical cord blood was collected immediately after delivery. The samples were chilled at $\left(+4^{\circ} \mathrm{C}\right)$ until 
delivery to the laboratory CERBA France for detection of the trace elements. Inductively Coupled Plasma Mass Spectrometry (ICP/MS Agilent $7700 \mathrm{CE}$ and $7500 \mathrm{CE}$ ) was used to measure the concentrations of lead and cadmium for 60 samples umbilical cord blood (30 samples for each metal).Thereafter ,Mercury concentrations have been measured from 10 samples umbilical cord blood, by Atomic absorption spectrophotometer (AAS, FIMS 400 Perkin Elmer) in the same laboratory. Recapitulating, lead was measured in 30 subjects, cadmium in 30 and mercury in 10 subjects. The detection limits for this study were as follows: Blood Pb $(0.1 \mu \mathrm{g} / \mathrm{dL}), \mathrm{Cd}(0.2 \mu \mathrm{g} / \mathrm{L})$, totalHg ( $5 \mathrm{nmol} / \mathrm{L})$.

The data collected during the research were analyzed using the statistical software (Spss version 22). To report the results we used a descriptive analysis method, calculating the means and standard deviations for the continuous data, the means were then compared using the Student's Test, for the nominal data we calculated the percentages of the different categories. Differences in patient's level of Mercury, lead and Cadmium according to different variables were assessed using the ANOVA test.

We evaluated the impact of the different heavy metals analyzed on birth weight and gestational age using the Pearson correlation. The result is reported in form tables and curves.

These statistical tests were considered significant if $\mathrm{p}<0.05$.

\section{RESULTS:}

A total of 70 deliveries were reported during the study period, lead and cadmium were measured in 30 subjects respectively and mercury in 10 subjects. The study showed obvious variations in maternal characteristics, socioeconomic status and obstetric/ gynecological history. We defined three groups; lead dosage group (30 subjects), cadmium dosage group (30 subjects), and mercury dosage group (10subjects).

Concentration of lead, cadmium and mercury in umbilical cord:

The dosage of these three metals revealed the following concentrations: lead concentrations ranging between 0 and $75 \mu \mathrm{g} / \mathrm{L}(18.97 \pm 14.22 \mu \mathrm{g} / \mathrm{L})$, cadmium between 0 and
$0.4 \mu \mathrm{g} / \mathrm{L}(0.26 \pm 0.07 \mu \mathrm{g} / \mathrm{L})$, mercury concentrations ranged between 0 and $9 \mathrm{nmol} / \mathrm{L}(6.20 \pm 1.64 \mathrm{nmol} / \mathrm{L})$. (Table1)

Relationship between concentration of metals and maternal characteristics

The average concentration was measured for each metal, $\mathrm{Pb}$, $\mathrm{Cd}$ and mercury in the cord blood and were all correlated with maternal characteristics (Table2).

\section{Lead concentrations and maternal characteristics}

The difference between the different Age groups of mothers and lead concentrationswas statistically significant $(\mathrm{P}<0.001)$, the highest rate of lead $(20.57 \pm 11.01)$ is found in the category over 35 years old(Table2). In this group, a single subject less than 20 years old has a high level of lead $(73.3 \mu \mathrm{g} / \mathrm{L})$, this result cannot have statistical significance. According to statistical analysis, patients with low socioeconomic status have the highest rates of lead (28.14 \pm 22.05$)$ (Table2). No other statistically significant relationship could be detected between lead and the rest of the maternal characteristics studied (Table2)

\section{Cadmium concentrations and maternal characteristics}

Regarding the relationship between cadmium concentrations and maternal characteristics, our results did not reveal any statistically significant relation (Table2)

\section{Mercury concentrations and maternal characteristics}

Our result observed a significant relationship between birth weight, History of abortion and mercury concentrations $(\mathrm{P}=$ 0.012). No other statistically significant relationship could be detected between mercury and the rest of the maternal characteristics studied (Table2)

\section{Correlation between gestational age, birth weight and} cord concentrations of lead, cadmium and mercury:

As shown in figure 1, a highly significant direct correlation was found between cord lead concentrations and gestational age $(\mathrm{r}=0.55 ; \mathrm{P}=0.002)$. Furthermore, a clear correlation was found between the concentration of cadmium in the umbilical cord and the birth weight ( $\mathrm{r}=0.25)$, (figure 2), (Table 3). Finally we found that gestational age and birth weight inversely correlated with cord mercury concentration ( $r=0.44$ and $r=0.57$ respectively), (figure 3).

Table1. Distribution of Lead, Cadmium and mercury concentrations in cord blood

\begin{tabular}{|c|c|c|}
\hline Variable & Médiane & interquartile range \\
\hline Cadmium $\boldsymbol{\mu g} / \mathbf{L}$ & 0,20 & $0,20-0,30$ \\
\hline Lead $\boldsymbol{\mu g} / \mathbf{L}$ & 15,15 & $10,35-21,75$ \\
\hline Mercury $\mathbf{~ n m o l / L ~}$ & 1,20 & $1,00-1,50$ \\
\hline
\end{tabular}


Table2.Relationship between concentration of metals and characteristics of the mother

\begin{tabular}{|c|c|c|c|c|c|c|c|c|c|c|c|c|}
\hline & \multicolumn{4}{|c|}{ Lead $(n=30)$} & \multicolumn{4}{|c|}{ Cadmium $(n=30)$} & \multicolumn{4}{|c|}{ Mercury $(n=10)$} \\
\hline Characteristics & $\mathbf{N}$ & $\begin{array}{l}\text { Mean } \\
\text { Rank }\end{array}$ & $\begin{array}{l}\text { Mann- } \\
\text { Whitney } \\
\text { U-test }\end{array}$ & $\begin{array}{l}P \\
\text { value }\end{array}$ & $\mathbf{N}$ & $\begin{array}{l}\text { Mean } \\
\text { Rank }\end{array}$ & $\begin{array}{l}\text { Mann- } \\
\text { Whitney } \\
\text { U-test }\end{array}$ & $\begin{array}{l}P \\
\text { value }\end{array}$ & $\mathbf{N}$ & $\begin{array}{l}\text { Mean } \\
\text { Rank }\end{array}$ & $\begin{array}{l}\text { Mann- } \\
\text { Whitney } \\
\text { U-test }\end{array}$ & $\begin{array}{l}P \\
\text { value }\end{array}$ \\
\hline $\begin{array}{l}\text { History of } \\
\text { prematurity }\end{array}$ & & & & & & & & & & & & \\
\hline YES & 3 & 14,67 & 38,000 & 0,86 & 5 & 11,75 & 31,000 & 0,76 & 3 & 3,50 & 1,500 & 0,70 \\
\hline No & 27 & 15,59 & & & 25 & 10,82 & & & 7 & 2,88 & & \\
\hline History of abortion & & & & & & & & & & & & \\
\hline YES & 9 & 13,44 & 76,000 & 0,40 & 6 & 14,00 & 22,000 & 0,23 & 3 & 5,00 & 1,491 & 0,13 \\
\hline No & 21 & 16,38 & & & 24 & 10,29 & & & 7 & 2,50 & & \\
\hline Level of education & & & & & & & & & & & & \\
\hline Illiterate & 9 & 15,67 & 91,000 & 0,87 & 8 & 8,61 & 30,500 & 0,90 & 2 & 3,25 & 2,500 & 0,76 \\
\hline Secondary / university & 21 & 15,11 & & & 11 & 8,36 & & & 7 & 2,83 & & \\
\hline Passive smoking & & & & & & & & & & & & \\
\hline YES & 19 & 15,18 & 98,500 & 0,79 & 15 & 11,00 & 55,000 & 0,91 & & & & \\
\hline Non & 11 & 16,05 & & & 15 & 11,00 & & & & & & \\
\hline Residence & & & & & & & & & & & & \\
\hline Urban & 12 & 18,25 & 75,000 & 0,16 & 16 & 10,09 & 45,000 & 0,29 & 4 & 4,25 & 0,500 & 0,128 \\
\hline Rural & 18 & 13,67 & & & 14 & 12,00 & & & 6 & 2,17 & & \\
\hline Socio-economiclevel & & & & & & & & & & & & \\
\hline Low & 7 & 19,71 & 51,000 & 0,14 & 7 & 12,00 & 33,000 & 0,41 & 4 & 3,25 & 2,500 & 0,76 \\
\hline Normal & 23 & 14,22 & & & 23 & 9,86 & & & 6 & 2,83 & & \\
\hline
\end{tabular}

Table3. Spearman correlation of mother's age, gestational age, birth weight and BMI with levels of lead, cadmium and mercury

\begin{tabular}{|c|c|c|c|c|c|c|}
\hline & \multicolumn{2}{|c|}{ Lead } & \multicolumn{2}{c|}{ Cadmium } & \multicolumn{2}{c|}{ Mercury } \\
\hline & $\mathrm{R}$ & $\mathrm{P}$ & $\mathrm{R}$ & $\mathrm{P}$ & $\mathrm{R}$ & $\mathrm{P}$ \\
\hline Mother's age & 0,274 & 0,143 & -0.30 & 0,899 & $-0,304$ & 0,619 \\
\hline Gestational age & 0,550 & $0,002^{* *}$ & 0,005 & 0,982 & 0,152 & 0,807 \\
\hline Birth weight & 0,144 & 0,448 & 0,250 & 0,275 & 0,105 & 0,866 \\
\hline BMI & $-0,141$ & 0,458 & $-0,167$ & 0,470 & 0,108 & 0,863 \\
\hline
\end{tabular}




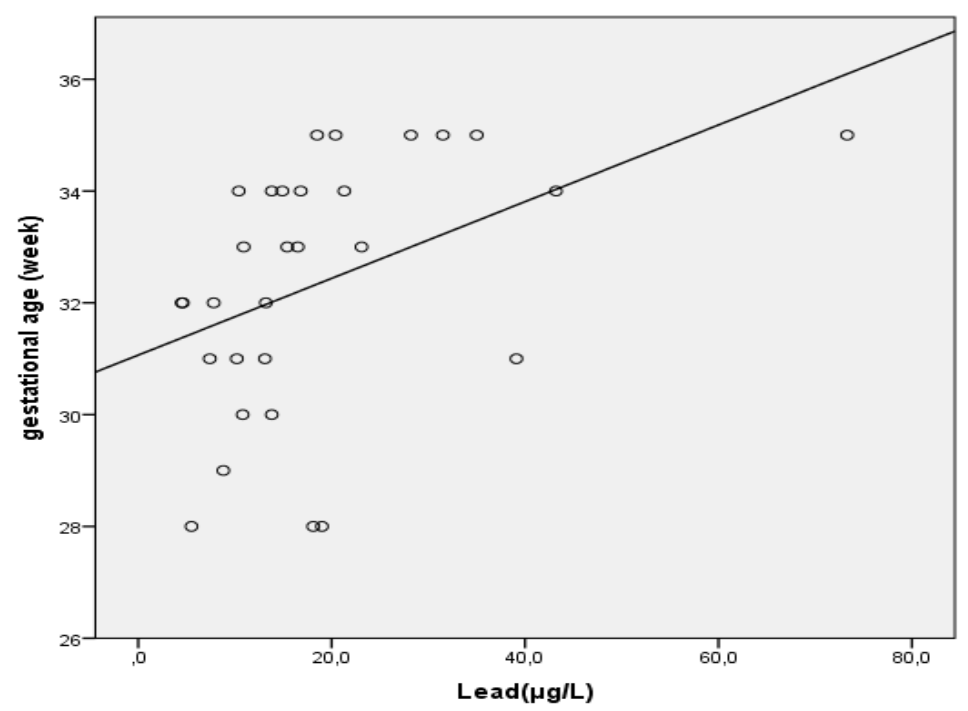

Figure 1: relation between Cord blood Lead and gestational age

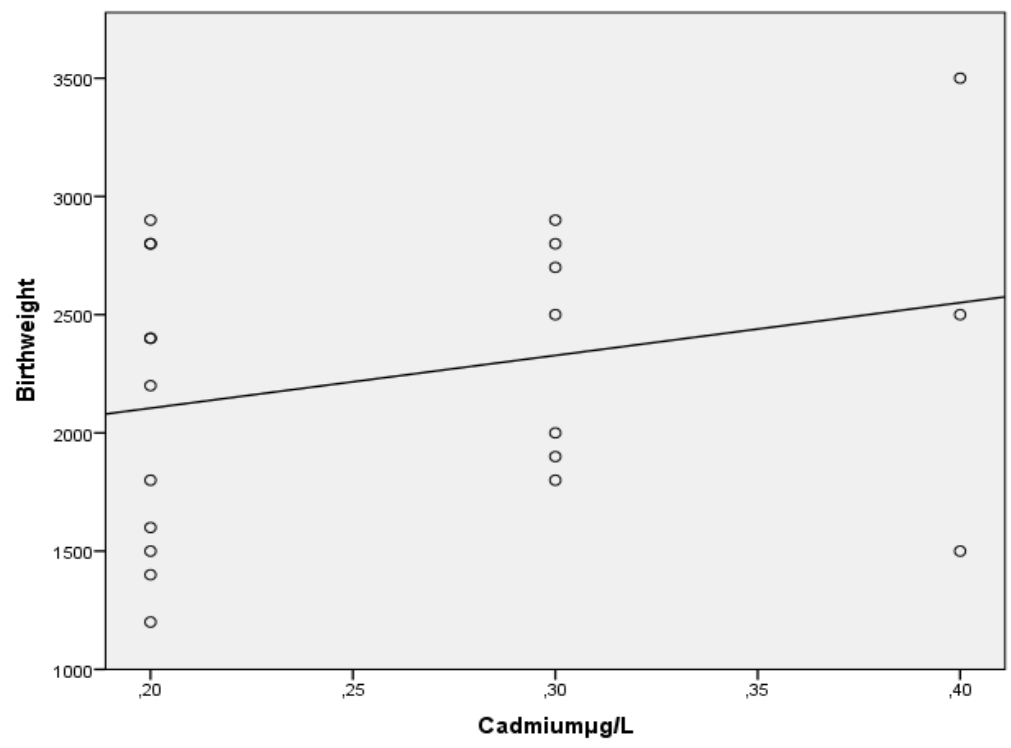

Figure 2: relation between Cord blood Cadmium and birth weight

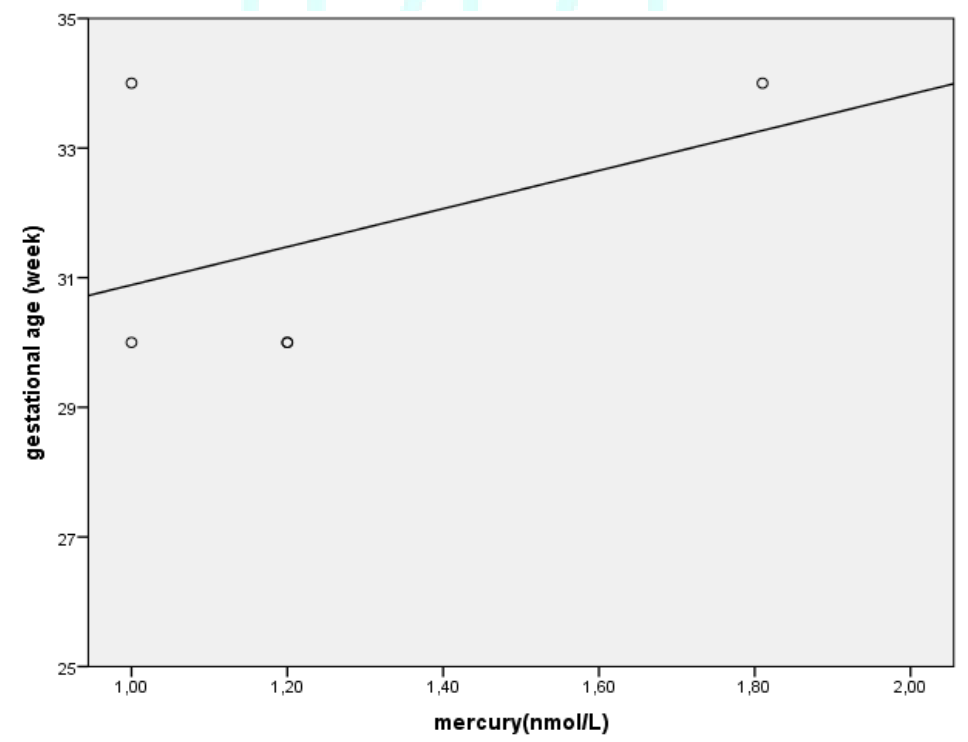

Figure 3: relation beween Cord blood Mercury and gestationnal age 


\section{DISCUSSION}

The mean concentration of lead in cord blood found in this study was $1.89 \mu \mathrm{g} / \mathrm{dL}$. Reports from South Africa a cord blood median lead concentration of $2.39 \mu \mathrm{g} / \mathrm{Dl}^{13}$. A Canadian study found a cord blood arithmetic mean lead concentration of $2.8 \mu \mathrm{g} / \mathrm{dL}$, and another study in Saudi Arabia found 2.5 $\mu \mathrm{g} / \mathrm{dl}^{14}$. Also, Mean cord blood lead was higher than those reported in Brazil were $(1.194 \mu \mathrm{g} / \mathrm{dL}){ }^{15}$.Belgium $(1.47 \mu \mathrm{g} / \mathrm{dL})$ and Turkey (Eskisehir; 1.65 $\mu \mathrm{g} / \mathrm{dL}$ ) 16,17,18.

In our study highly significant direct correlation was found between cord lead concentrations and gestational age $(\mathrm{P}=$ 0.017). Multiple studies have found an association with $\mathrm{SGA}^{7}$ $19,20,27$.

In our Study the meanconcentration of cadmium in cord blood was $0.26 \mu \mathrm{g} / \mathrm{L}$, a value lower than that reported in Saudi Arabia (GM $=0.78 \mu \mathrm{g} / \mathrm{L}$ ) 22,23 , and consistent with the values reported in many studies conducted in other areas in China $(\mathrm{GM}=0.20 \mu \mathrm{g} / \mathrm{L})^{24}, \mathrm{Nepal}(\mathrm{GM}=0.29 \mu \mathrm{g} / \mathrm{L})^{25}$.

Our findings that not exceed the allowed level determined by OHSA $(5 \mu \mathrm{g} / \mathrm{L})^{26,27,28}$. Pregnancy is a critical period in terms of cadmium toxicity, and several adverse outcomes such as preeclampsia, LBW, prematurity. Cadmium accumulates in the placenta interacting with the transport of micronutrients and may play a key role in the occurrence of intrauterine growth restriction 29,30 . In this study, we found a clear correlation between the concentration of cadmium in the umbilical cord and the birth weight, in literature two studies found no effect of cadmium on fetal growth outcomes 30,31 , while others found relationships with birth weight or length $32,33,34,35$.

The average mercury content in the cord was $2.24 \mu \mathrm{g} / \mathrm{L}$. this value was lower than the Environmental Protection Agency (EPA) reference dose of $5.8 \mu \mathrm{g} / \mathrm{L}^{36}$.

In our study mercury cord levels were higher than those found in Canada (Montreal; $0.69 \mu \mathrm{g} / \mathrm{L})$, Poland $(0.88 \mu \mathrm{g} / \mathrm{L}$ ), Slovakia $(0.8 \mu \mathrm{g} / \mathrm{L})$, South Africa $(1.2 \mu \mathrm{g} / \mathrm{L})$, Sweden (organic; $1.4 \mu \mathrm{g} / \mathrm{Land}$ inorganic; $0.34 \mu \mathrm{g} / \mathrm{L})$ and Turkey $(0.5 \mu \mathrm{g} / \mathrm{L})^{37}$.

Also, statistically significant relationship was observed between mercury exposure and abortion history in our study. Their teratogenic and foetotoxic roles were established. According to the WHO, it played a key role in the occurrence of spontaneous abortions $38,39,40$. However, later analysis of a more complete dataset disproved ${ }^{42}$.Concerning level of mercury and gestational age, four studies used mercury measurements in cord blood and maternal blood with higher exposure levels with larger samples than our study found an association between mercury and small gestational age 20,41 .

\section{CONCLUSION}

The results of the present study provide relatively comprehensive information concerning the $\mathrm{Pb}, \mathrm{Cd}$ and $\mathrm{Hg}$ levels in the cord of preterm newborns from west of Algeria. This study has shown that pregnant women in this region of the country were exposed to similar levels, compared to pregnant women in industrialized countries, or even higher levels for lead. Further research incorporating larger samples is needed to investigate the effects of pregnant women's exposure to heavy metals - particularly $\mathrm{Pb}, \mathrm{Cd}, \mathrm{Hg}$ and its impact on small gestational age. The health effects of prenatal exposure to heavy metals as well as to other pollutants to which human population is exposed should alert countries governments to endorse stricter standards and tighten legislation to protect future generations from diseases that may develop following prenatal exposures

\section{Conflict of interest}

Authors declared they have no competing of interest.

\section{REFFERENCES}

1. Health Canada, Arsenic - Guidelines for Canadian Drinking Water Quality: Guideline Technical Document. Available from: 〈http://www.hc-sc.gc.ca/ewh- semt/pubs/watereau/arsenic/index-eng.php $;$; (2006): (cited 01.08.13)

2. Sanders T, Liu Y, Buchner V, Tchounwou PB. Neurotoxic effects and biomarkers of lead exposure: a review. Rev Environ Health 2009; 24:15-45

3. Myatt, Placental adaptive responses and fetal programming. J.Physiol. 2006; 572:25-30

4. Thomas R. Frieden, MD, MPH Lead Poisoning in Pregnant Women Who Used Ayurvedic Medications from India. Centers for Disease Control and Prevention.2012; 61:33.

5. Vigeh M, Yokoyama K, Kitamura F, AfshinrokhM, Beygi A, Niroomanesh. Early pregnancy blood lead and spontaneous abortion. Women Health.2010; 50:756-66

6. Bellinger DC. Teratogen update: lead and pregnancy. Birth Defects Res A ClinMol Teratol.2005; 73:409-20

7. Chen PC, Pan IJ, Wang JD. Parental exposure to lead and small for gestational age births. Am J Ind Med. 2006; 49:417-22

8. Tchounwou PB, Yedjou CG, Patlolla AK, Sutton DJ. Heavy Metals Toxicity and the Environment. EXS. 2012; 101:133-164

9. Raymond A. Wuana and Felix E. Okieimen. "Heavy Metals in Contaminated Soils: A Review of Sources, chemistry, Risks and Best Available Strategies for Remediation," ISRN Ecology. 2012; 20

10. Erbi P. Ikeh-Tawari. John.Anetor. M. A. Charles- Davies. Cadmium Level in Pregnancy, Influence on Neonatal Birth Weight and Possible Amelioration by Some Essential Trace Elements. Toxico.Int.2013; 20(1):108-112

11. Thomas Nissen. An In-depth Report on the Effects of Mercury Poisoning Toxicity, Evenbetterhealth.com.2010.

12. Bernard, A.M. Biokinetics and stability aspects of biomarkers: recommendations for application in population studies. Toxicology.1995; 101:65-71

13. Röllin HB, Rudge CV, Thomassen Y, Mathee A, Odland JØ. Levels of toxic and essential metals in maternal and umbilical cord blood from selected areas of South Africa--results of a pilot study. J Environ Monit.2009; 11:618-27

14. Butler Walker J, Houseman J, Seddon L, McMullen E, Tofflemire K, Mills C.et al. Maternal and umbilical cord blood levels of mercury, lead, cadmium, and essential trace elements in Arctic Canada. Environ Res.2006; 100:295-318

15.Amaral, J.H., Rezende, V.B., Quintana, S.M., Gerlach, R.F., Barbosa F.Jr., Tanus-Santos,J.E.The relationship between blood and serum lead levels in peri-partum women and their respective umbilical cords. basicClin. Pharmacol. Toxicol. 2010

16.Koppen, G., Den Hond, E., Nelen, V., Van De Mieroop, E., Bruckers, L., Bilau, M., Keune,H., Van Larebeke, N., covaci, A., Van De Weghe, H., Schroijen, C., Desager, K., Stalpaert, M., Baeyens, W., Schoeters, G. organ chlorine and heavy metals in new-born's: Results from the Flemish Environment and health Survey (FLEHS2002-2006). Environ. Int.2009; 35:1015-1022

17. Kirel, B., Akit, M.A., Bulut, and H. Blood lead levels of maternalcord pairs, children and adults who live in a central urban area in Turkey. Turk. J. Pediatr.2005; 47:125-131

18. Bismuth C., Baud F., Conso F. Toxicologie clinique. Flammarion Médecine-Sciences, 5ème édition, Paris. 2012; 1092.

19. Chen LH, Petitti DB Case-control study of passive smoking and the risk of small-for-gestational-age at term. Am J Epidemiol. 1995; 142(2):158-165. 
20. Shari Thomas, TyeE. Arbuckle, Mandy Fisher, William D. Fraser, Adrienne Ettinger, Will King. Metals exposure and risk of smallfor-gestational age birth in a Canadian birth cohort: The MIREC study. Environmental research.2015; 140:430-439.

21. Perkins M, Wright RO, Amarasiriwardena CJ, et al. Very low maternal lead level in pregnancy and birth outcomes in an eastern Massachusetts population. Ann Epidemiol.2014; 24:9159

22. Satarug, S., Moore, M.R. Adverse health effects of chronic exposure to low-level cadmium in foodstuffs and cigarette smoke. Environ. Health Perspect.2004; 112:1099-1103

23.Al-Saleh, I., Shinwari, N., Mashhour, A., Rabah, A. Birth outcome measures and maternal exposure to heavy metals (lead, cadmium and mercury) in Saudi Arabian population. Int. J. Hyg. Environ. Health. 2013

24.Zhang, Y.L., Zhao, Y.C., Wang, J.X., Zhu, H.D., Liu, Q.F., Fan, Y.G., Wang, N.F., Zhao, J.H., Liu, H.S., Ou-Yang, L., Liu, A.P., Fan, T.Q. Effect of environmental exposure to cadmium on pregnancy outcome and fetal growth: a study on healthy pregnant women in China. J. Environ. Sci. Health A Tox. Hazard subst. Environ. Eng.2004; 39:2507-2515

25.Parajuli, R.P., Fujiwara, T., Umezaki, M., Furusawa, H., Ser, P.H., Watanabe, C. Cord blood levels of toxic and essential trace elements and their determinants in the Terai region of Nepal: a birth cohort study. Biol. traces Elem. Res.2012; 147:75-83

26. OSHA (Occupational Safety and Health Administration) Occupational Exposure to Cadmium: Final Rules. US Department of Labor, Federal Register.1992; 57:42101-42463

27. Jarup, L., Akesson, A. Current status of cadmium as an environmental health problem. Toxicol. Appl. Pharmacol.2009; 238:201-208

28.Guan, H., Piao, F.Y., Li, X.W., Li, Q.J., Xu, L., Yokoyama, K. Maternal and foetal exposure to four carcinogenic environmental metals. Biomed. Environ. Sci.2010; 23:458-465

29. Thompson J, Bannigan J. Cadmium: toxic effects on the reproductive system and the embryo. Reprod Toxicol.2008; 25(3):304-15

30.Yang Q, Wen SW, Smith GN, Chen Y, Krewski D, Chen XK, et al. Maternal cigarette smoking and the risk of pregnancy-induced hypertension and eclampsia. International journal of epidemiolog.2006; 35:288-93

31. Loiacono,N.J., Graziano,J.H., Kline,J.K., Popovac,D., Ahmedi,X., Gashi,E., etal. Placental cadmium and birth weight in women living near aleadsmelter. Arch. Environ. Health.1992; 47:250255

32. Kippler, M., Tofail, F., Gardner, R., Rahman, A., Hamadani, J.D., Bottai, M., et al. Maternal cadmium exposure during pregnancy and size at birth: prospective cohort study. Environ. Health Perspect. 2011; 120:284-289

33. Nishijo,M., Tawara,K. ,Honda,R. ,Nakagawa, H., Tanebe, K., Saito, S. Relationship between new born size and mother's blood cadmium levels Toyama, Japan. Arch.Environ.Health.2004; 59:22-25

34.Tian, L.-L., Zhao, Y.-C., Wang, X.-C., Gu, J.-L.,Sun, Z.-J., Zhang, Y.-L., et al. Ef- facts of gestational cadmium exposure on pregnancy outcome and development in the offspring at age 4.5 years. Biol. Trace Elem.Res.2009; 132:51-59

35. Murphy VE, Smith R, Giles WB, Clifton VL. Endocrine regulation of human foetal growth: the role of the mother, placenta, and fetus. Endocr Rev.2006; 27:141-69

36. US EPA, Environmental Protection Agency. Mercury. Human exposure Available:

(accessed 13.03.2007) http://www.epa.gov/mercury/exposure.htm.

37. Al-Saleh I, , Shinwaria N, Mashhoura A, Gamal El Din M, Rabah A. Heavy metals (lead, cadmium and mercury) in maternal, cord blood and placenta of healthy women. International Journal of Hygiene and environmental Health.2011; 214:79-101

38. Word health organization. Elementary mercury and inorganic mercury compounds. Human health aspects. Concise international chemical Assessment. Document 50. Geneva, 2003.

39. Urbach,J., Boadi, W., Brandes, J.M., Kerner,H., Yannai, S. Effect of inorganic mercury on in vitro placental nutrient transfer and oxygen consumption. Re- prod. Toxicol.ElmsfordNY.1992; 6:6975

40. Jedrychowski,W., Jankowski, J., Flak, E.,S karupa,A., Mroz,E., Sochacka-Tatara, E., et al. Effects of prenatal exposure to mercury on cognitive and psycho- motor function in one-yearold infants: epidemiologic cohort study in Poland. Ann. Epidemiol. 2006; 16:439-447

41. Foldspang, A., Hansen, J.C. Dietary intake off methyl mercury as a correlate of gestational length and birth weight among new borns in Greenland. Am.J. Epidemiol.1990; 132:310-317

42. Lee, B.-E., Hong, Y.-C., Park, H., Ha, M., Koo, B.S., Chang, N., et al. Interaction between GSTM1/GSTT1 Polymorphism and Blood Mercury on Birth Weight. Environ Health Perspect.2010; 118:437-44 